\title{
Chloride anion effect on the advanced oxidation processes of methidathion and dimethoate: Role of $\mathrm{Cl}_{2}^{--}$radical
}

\author{
Paula Caregnato ${ }^{a}$, Janina A. Rosso ${ }^{a}$, Juán M. Soler ${ }^{b}$, Antonio Arques $^{b}$, Daniel O. Mártire ${ }^{a}$, \\ Mónica C. Gonzalez ${ }^{a, *}$ \\ a Instituto de Investigaciones Fisicoquímicas Teóricas y Aplicadas (INIFTA), Facultad de Ciencias Exactas, Universidad Nacional de La Plata, \\ Casilla de Correo 16, Sucursal 4, (1900) La Plata, Argentina \\ ${ }^{\mathrm{b}}$ Grupo de Procesos de Oxidación Avanzada, Departamento de Ingeniería Textil y Papelera, Universidad Politécnica de Valencia, \\ Campus de Alcoy, Plaza Ferrandiz y Carbonell s/n, 03801 Alcoy, Spain
}

\section{A R T I C L E I N F O}

Article history:

Received 4 July 2012

Received in revised form

2 October 2012

Accepted 6 October 2012

Available online 23 October 2012

Keywords:

Organophosphorous pesticides

Degradation

Chloride anion

Flash-photolysis

Chlorinated byproducts

\begin{abstract}
A B S T R A C T
The reaction of phosphor-containing pesticides such as methidathion (MT) and dimethoate (DM) with dichloride radical anions $\left(\mathrm{Cl}_{2}^{-}\right)$was investigated. The second order rate constants $(1.3 \pm 0.4) \times 10^{8}$ and $(1.1 \pm 0.4) \times 10^{8} \mathrm{M}^{-1} \mathrm{~s}^{-1}$ were determined for the reaction of $\mathrm{Cl}_{2}^{-}$with MT and DM, respectively. A reaction mechanism involving an initial charge transfer from the sulfide groups of the insecticides to $\mathrm{Cl}_{2}^{--}$is proposed and supported by the identified transient intermediates and reaction products. The formation of chlorinated byproducts was determined. The unexpected consequences of an efficient $\mathrm{Cl}_{2}^{-}$reactivity towards MT and DM on the degradation capacity by Advanced Oxidation Procedures applied to polluted waters containing the insecticides and $\mathrm{Cl}^{-}$anions is discussed.
\end{abstract}

(c) 2012 Elsevier Ltd. All rights reserved.

\section{Introduction}

Advanced Oxidation Processes (AOPs) are reported to be a promising alternative to remediate effluents which cannot be treated by conventional biological treatments. Most AOPs involve the in situ generation of highly reactive species such as hydroxyl and sulfate radicals, which are able to oxidize a wide range of chemicals. Ozone-based oxidation procedures, titanium dioxide heterogeneous photocatalysis and the photoFenton process are among the most widely employed AOPs capable of removing toxic pollutants, such as pesticides. However, the presence of phosphates, carbonates, chlorides and surfactants in the water matrix has a remarkable influence on the process as they may decrease their efficiency (Soler et al., 2009; De Laat and Le, 2006; Machulek et al., 2007; Mora et al., 2009; Dell'Arciprete et al., 2012; Tsuneda et al., 2002; Boncz et al., 2005).

The presence of chloride anions in groundwater and surface water in rural and urban areas is widespread. The input of $\mathrm{NaCl}$ from seawater intrusion along coastal areas, animal and human waste in rural areas, leaking landfills, and natural saline seeps, has created progressively worsening problems with water quality (Panno et al., 2002). Therefore, the effect of $\mathrm{Cl}^{-}$on AOPs pollutant degradation is an important factor to account for, since $\mathrm{Cl}^{-}$efficiently scavenges $\mathrm{HO} \cdot$ and $\mathrm{SO}_{4}^{-}$radicals (Ross et al., 1998) and is able to form $\mathrm{Fe}^{3+}$ complexes in

\footnotetext{
* Corresponding author. Tel.: +54 221425 7430; fax: +54 2214254642 .

E-mail address: gonzalez@inifta.unlp.edu.ar (M.C. Gonzalez). 
photo-Fenton processes (Machulek et al., 2007). These effects lead to the formation of chlorine-containing radicals, namely $\mathrm{Cl}_{2}^{-} / \mathrm{Cl}$ (Machulek et al., 2007; Liu et al., 2010) and a concomitant reduction in the active oxidant yield. However, organic compounds can also react with $\mathrm{Cl}$ atoms and $\mathrm{Cl}_{2}^{-}$radicals; hence, the presence of these radicals in the reaction media might produce changes in the photo-oxidative pathways and formation of undesirable toxic chlorinated byproducts (Liu et al., 2010). In fact, reported computer simulations (De Laat and Le, 2006) on the rates of decomposition of $\mathrm{H}_{2} \mathrm{O}_{2}$ by ferric ion and on the rate of oxidation of an organic solute in the presence of $\left[\mathrm{Cl}^{-}\right]>10 \mathrm{mM}$, showed that more than $99 \%$ of the generated $\mathrm{HO} \cdot$ are converted into $\mathrm{Cl}_{2}^{--}$. Therefore, the formation rate and reactivity of $\mathrm{Cl}_{2}^{-}$radicals must be taken into account in the evaluation of the AOP efficiency when applied to systems containing high concentrations of chloride anions. The determination of the kinetic parameters and pathways of the reactions involving $\mathrm{Cl}_{2}^{-}$radicals are important input parameters in the development of kinetic models. These models provide a basis for the design and process improvement through facile exploration of diverse processing scenarios (Chong et al., 2010; Peyton, 1990; Susnow et al., 1997).

The removal of phosphor-containing pesticides, such as methidathion (MT) and dimethoate (DM) (see Scheme 1), by photo-Fenton is well reported in the literature (Ballesteros et al., 2009; Oller et al., 2005). The solar photo-Fenton treatment at pilot plant scale of a mixture of four commercial pesticides also containing MT and DM showed similar chemical composition and comparable biocompatibility, though longer irradiation periods were needed to reach the desired mineralization when $\mathrm{Cl}^{-}$was present (Soler et al., 2009). In the present manuscript we investigate the kinetics and reaction mechanisms of $\mathrm{Cl}_{2}^{-}$radical anions with $\mathrm{MT}$ and $\mathrm{DM}$ and evaluate the importance of these reactions during the AOP treatment of a polluted water containing both, the insecticides and chloride anions.

\section{Material and methods}

\subsection{Reagents}

The pesticides employed in this work, MT and DM were purchased from Sigma-Aldrich (Pestanal). Sodium chloride and sodium peroxodisulfate were obtained from Merck. Water

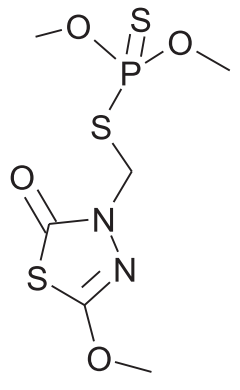

MT

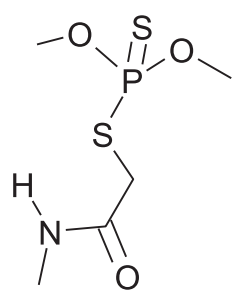

DM
Scheme 1 - Chemical structure of the insecticides methidathion (MT) and dimethoate (DM). employed in all experiments was Milli $Q$ grade ( $>18 \mathrm{M} \Omega \mathrm{cm}<20 \mathrm{ppb}$ organic carbon). The $\mathrm{pH}$ of the samples was measured with a Consort C832 pH-meter.

\subsection{Conventional flash photolysis experiments}

Flash-photolysis experiments were carried out using a conventional apparatus, Xenon Co. model $720 \mathrm{C}$ with modified optics and electronics. Two collinear quartz Xenon highintensity pulsed flash tubes, Xenon Corp. P/N 890-1128 (FWHM $\leq 20 \mu \mathrm{s}$ ), with a continuous spectral distribution ranging from 200 to $600 \mathrm{~nm}$ and maximum around $450 \mathrm{~nm}$ were used. The analysis source was a high pressure mercury lamp (Osram HBO-100 W). The optical path length of the $1 \mathrm{~cm}$ internal diameter quartz sample cell was $10 \mathrm{~cm}$. The monochromator collecting the analysis beam (Bausch \& Lomb, high-intensity) was directly coupled to a photomultiplier (RCA 1P28), which output was fed into a digital oscilloscope (HP 54600B). Digital data were stored in a personal computer. The emission of the flash lamps was filtered with an aqueous solution highly concentrated in the corresponding organic compound in order to avoid photolysis of the substrate. In fact, flash-photolysis experiments of aqueous solutions of the insecticides in the absence of persulphate showed no transient signals, further supporting that the insecticides photolysis is of no significance under these experimental conditions. The temperature $\left(20 \pm 3^{\circ} \mathrm{C}\right)$ was measured inside the reaction cell with a calibrated Digital Celsius Pt-100 $\Omega$ thermometer. Freshly prepared solutions were used in order to avoid possible thermal reactions of peroxodisulfate with the substrates. To avoid product accumulation, each solution was irradiated only once.

\subsection{Bilinear regression analysis}

For each experimental condition, several absorbance decay profiles at different detection wavelengths were taken. Absorbance is thus a function of wavelength and time. Taking advantage of the linearity of the absorbance with both, concentrations and absorption coefficients, a bilinear regression analysis was applied to the experimental absorption matrix in order to retrieve information on the minimum number of species and on their relative concentration profiles and absorption spectra (San Roman and Gonzalez, 1989).

\subsection{Computer simulations}

The kinetic model for computer simulation is based on component balances and equilibrium equations formulated in terms of a differential algebraic equations system which is solved by Gear's Stiff method and a least squares estimation criterion as described elsewhere (Alegre et al., 2000).

\subsection{Determination of byproducts}

In order to identify the main reaction products formed after the reaction of $\mathrm{Cl}_{2}^{-}$with the insecticides, $250 \mathrm{~mL}$ of solutions containing sodium chloride, the pesticide and sodium peroxodisulfate were irradiated using a cylindrical reactor described elsewhere (Dell'Arciprete et al., 2010). An axial immersion low- 
pressure mercury lamp Heraeus TNN 15/35 which emits nearly monochromatic radiation at $254 \mathrm{~nm}$ was used as irradiation source. Ratios of $\left[\mathrm{S}_{2} \mathrm{O}_{8}^{2-}\right] \times \varepsilon_{\mathrm{S}_{2} \mathrm{O}_{8}^{2-}}$ : [Insecticide] $\times \varepsilon_{(\text {Ins })}>100$, with $\varepsilon$ the molar absorption coefficient, were used to minimize the photolysis of the pesticides. The latter conditions hold for $[\mathrm{MT}]=3 \times 10^{-4} \mathrm{M}$ in solutions containing $\left[\mathrm{S}_{2} \mathrm{O}_{8}^{2-}\right]=0.25 \mathrm{M}$, and $[D M]=1 \times 10^{-3} \mathrm{M}$ in solutions containing $\left[\mathrm{S}_{2} \mathrm{O}_{8}^{2-}\right]=0.1 \mathrm{M}$, used in these experiments. Chloride concentration was $4 \mathrm{M}$.

After selected periods of irradiation, the reactor was emptied and the treated solution was concentrated by means of solid phase extraction: $100 \mathrm{~mL}$ of the aqueous solution were flown though a LiChrolut EN 200 mg (Merck) cartridge and the adsorbed organics recovered with $3 \mathrm{~mL}$ of methanol. A GCMSQP2010S (Shimadzu) gas chromatograph equipped with a quadrupole mass analyzer was employed to identify major intermediates formed along the process. The temperature program for GC analysis involved an increase from $60{ }^{\circ} \mathrm{C}$ to $250{ }^{\circ} \mathrm{C}$ at a rate of $5{ }^{\circ} \mathrm{C} / \mathrm{min}$ rate. A Meta X5 Teknokroma column was used. The determination of the derived intermediates was conducted by interpretation of the mass spectrum and further comparison of the identified product spectrum with those reported in the literature (Evgenidou and Konstantinou, 2006).

\section{Results}

\subsection{Rate constant determination for the reaction of $\mathrm{Cl}_{2}^{-}$ with MT and DM}

Dichloride radical anions, $\mathrm{Cl}_{2}^{-}$, were formed by reaction of chloride ions with sulfate radical anions, $\mathrm{SO}_{4}^{-}$, generated upon the UV-photolysis of $\mathrm{S}_{2} \mathrm{O}_{8}^{2-}$ solutions of pH $5.5 \pm 0.5$ (George and Chovelon, 2002), reaction (1) in Table 1 . In the presence of chloride at concentrations $>10^{-4} \mathrm{M}$ (Alegre et al., 2000), $\mathrm{SO}_{4}^{--}$radicals are readily depleted yielding chlorine atoms, as shown in reaction (2). Reaction of $\mathrm{Cl}$ with $\mathrm{Cl}^{-}$ions reversibly yields $\mathrm{Cl}_{2}^{-}$radical ions, reactions (3) and (4). Both, $\mathrm{Cl}$ and $\mathrm{Cl}_{2}^{-}$ radicals absorb below $380 \mathrm{~nm}$ with molar absorption coefficients at $340 \mathrm{~nm}, \varepsilon^{340}=3800 \mathrm{M}^{-1} \mathrm{~cm}^{-1}$ (Yu, 2004) and $9600 \pm 500 \mathrm{M}^{-1} \mathrm{~cm}^{-1}$ (Nagarajan and Fessenden, 1985), respectively.

Time-resolved experiments with $0.6 \mathrm{M}>\left[\mathrm{Cl}^{-}\right]>0.3 \mathrm{M}$ and $\left[\mathrm{S}_{2} \mathrm{O}_{8}^{2-}\right]=1.5 \times 10^{-2} \mathrm{M}$ performed with the conventional flashphotolysis apparatus show a transient species with an absorption maximum at $340 \mathrm{~nm}$, whose spectrum is in agreement with that reported for the $\mathrm{Cl}_{2}^{--}$radical ions (Adams et al., 1995). The concentration of $\mathrm{Cl}_{2}^{-}$is expected to be much higher than that of $\mathrm{Cl}$ under our experimental conditions, as the equilibrium constant for the reversible reactions (3) and (4)(3) and (4) is $\mathrm{K}_{3,4}=1.4 \times 10^{5} \mathrm{M}^{-1}$ at $298 \mathrm{~K}$ (Buxton et al., 1998). Hence $\varepsilon\left(\mathrm{Cl}_{2}^{-}\right) \times\left[\mathrm{Cl}_{2}^{--}\right] / \varepsilon(\mathrm{Cl}) \times[\mathrm{Cl}]>1.1 \times 10^{5} \mathrm{M}^{-1}$ is obtained, thus indicating that the absorbance of chlorine atoms is negligible compared to that of $\mathrm{Cl}_{2}^{-}$.

Flash-photolysis experiments performed with solutions containing $0.6 \mathrm{M}>\left[\mathrm{Cl}^{-}\right]>0.3 \mathrm{M},\left[\mathrm{S}_{2} \mathrm{O}_{8}^{2-}\right]=1.5 \times 10^{-2} \mathrm{M}$, and either DM or MT at concentrations lower than $6.25 \times 10^{-5} \mathrm{M}$ also show fast formation of $\mathrm{Cl}_{2}^{-}$. In the presence of increasing insecticide concentrations, the decay of the transient is accelerated (see Fig. 1 for experiments in the presence and
Table 1 - Manifold of reactions taking place upon UVlight activation of peroxodisulfate in the reaction mixture containing $\mathrm{S}_{2} \mathrm{O}_{8}^{2-}, \mathrm{Cl}^{-}$, and the insecticide. The

corresponding rate constants, $k$, at $25^{\circ} \mathrm{C}$ are also shown. The acronym INS stands for MT or DM.

$$
\begin{aligned}
& k / \mathrm{M}^{-1} \mathrm{~s}^{-1 \mathrm{a}} \\
& \mathrm{S}_{2} \mathrm{O}_{8}^{2-}+h v \rightarrow 2 \mathrm{SO}_{4}^{--} \quad \nu=\mathrm{I}_{\mathrm{abs}} \times \phi\left(\mathrm{SO}_{4}^{--}\right)^{\mathrm{b}} \\
& \mathrm{SO}_{4}^{--}+\mathrm{Cl}^{-} \rightarrow \mathrm{Cl}+\mathrm{SO}_{4}^{2-} \quad 4.7 \times 10^{8} \text { at } \mathrm{I}=0.1 \mathrm{M}^{\mathrm{c}} \\
& \mathrm{Cl}+\mathrm{Cl}^{-} \rightarrow \mathrm{Cl}_{2}^{-} \quad 8.5 \times 10^{9 \mathrm{c}} \\
& \mathrm{Cl}_{2}^{--} \rightarrow \mathrm{Cl}+\mathrm{Cl}^{-} \quad 6.0 \times 10^{4} \mathrm{~s}^{-1 \mathrm{c}} \\
& \mathrm{Cl}_{2}^{--}+\mathrm{Cl}_{2}^{--} \rightarrow \mathrm{Cl}_{2}+2 \mathrm{Cl}^{-} \quad 3.3 \times 10^{9 \mathrm{c}} \\
& \begin{array}{ll}
\mathrm{Cl}_{2}^{--}+\mathrm{INS} \rightarrow \text { Organic transient } & \begin{array}{l}
k_{6 \mathrm{MT}}=(1.3 \pm 0.4) \times 10^{8 \mathrm{~d}} \\
k_{6 \mathrm{DM}}=(1.1 \pm 0.4) \times 10^{8 \mathrm{~d}}
\end{array}
\end{array}
\end{aligned}
$$

$\mathrm{Cl}+\mathrm{INS} \rightarrow \mathrm{f}$

$$
\mathrm{Cl}+\mathrm{H}_{2} \mathrm{O} \rightarrow \mathrm{HO}^{\circ}+\mathrm{HCl} \quad 2 \times 10^{5} \mathrm{~s}^{-1 \mathrm{c}}
$$

$\mathrm{Cl}_{2}^{--}+\mathrm{H}_{2} \mathrm{O} \rightarrow \mathrm{HO}^{\cdot}+2 \mathrm{Cl}^{-}+\mathrm{H}^{+} \quad<1.3 \times 10^{3} \mathrm{~s}^{-1 \mathrm{c}}$

$\mathrm{Cl}_{2}^{--}+\mathrm{HO}^{-} \rightarrow \mathrm{HO}^{\cdot}+2 \mathrm{Cl}^{-} \quad 4 \times 10^{6} \mathrm{M}^{-1} \mathrm{~s}^{-1 \mathrm{c}}$

$$
\mathrm{HO}^{\bullet}+\mathrm{Cl}^{-} \rightarrow \mathrm{Cl}+\mathrm{HO}^{-} \quad 4.3 \times 10^{9} \mathrm{M}^{-1} \mathrm{~s}^{-1 \mathrm{c}}
$$

$$
\mathrm{HO}^{\circ}+\mathrm{INS} \rightarrow \quad \begin{aligned}
& k_{12 \mathrm{MT}}=7.1 \times 10^{9 \mathrm{e}} \\
& k_{12 \mathrm{DM}}=8.5 \times 10^{9 \mathrm{e}}
\end{aligned}
$$

$\mathrm{SO}_{4}^{--}+\mathrm{INS} \rightarrow \mathrm{f}$

$\mathrm{SO}_{4}^{--}+\mathrm{H}_{2} \mathrm{O} \rightarrow \mathrm{SO}_{4}^{2-}+\mathrm{HO}^{\cdot}+\mathrm{H}^{+} \quad(6.6 \pm 0.4) \times 10^{2 \mathrm{~g}}$

$\mathrm{SO}_{4}^{--}+\mathrm{S}_{2} \mathrm{O}_{8}^{2-} \rightarrow \mathrm{S}_{2} \mathrm{O}_{8}^{--}+\mathrm{SO}_{4}^{2-} \quad(6.3 \pm 1.5) \times 10^{5 g}$

$2 \mathrm{SO}_{4}^{--} \rightarrow \mathrm{S}_{2} \mathrm{O}_{8}^{2-} \quad 5 \times 10^{8 \mathrm{c}, \mathrm{g}}$

$2 \mathrm{HO}^{\circ} \rightarrow \mathrm{H}_{2} \mathrm{O}_{2} \quad 5.2 \times 10^{9 \mathrm{c}, \mathrm{g}}$

a Second order rate constants are given unless otherwise indicated.

$\mathrm{b} v$ is the rate of $\mathrm{SO}_{4}^{--}$formation, $\mathrm{I}_{\mathrm{abs}}$ is the absorbed photonic flux and $\phi\left(\mathrm{SO}_{4}^{-}\right)$is the peroxodisulfate photodissociation quantum yield.

c Yu (2004), Alegre et al. (2000), and Ross et al. (1998).

$d k$ values from this work.

e Marin et al. (2011).

f Assumed diffusion-controlled for simulation purposes, in agreement with reported rate constants for the reaction of $\mathrm{Cl}$ with organic sulfides (Ross et al., 1998).

g Herrmann et al. (1995). 


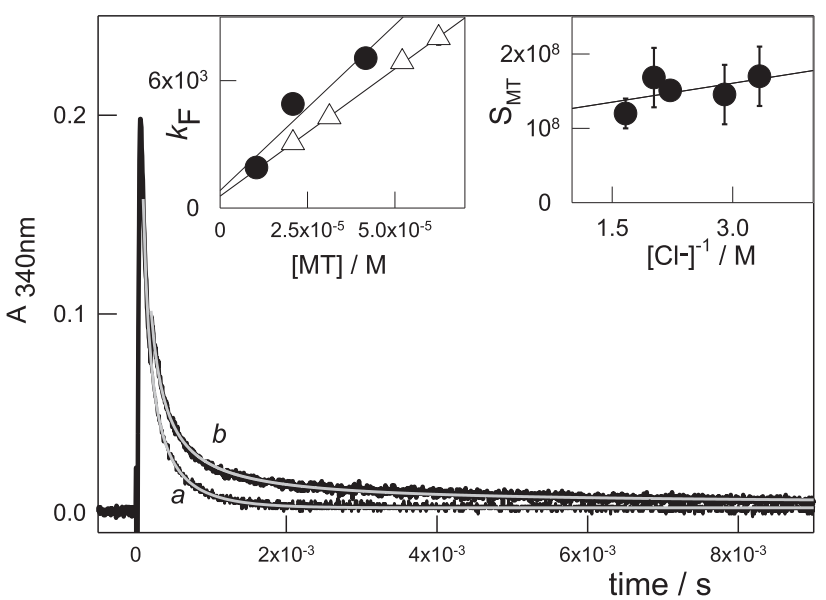

Fig. 1 - Absorbance traces at $340 \mathrm{~nm}$ obtained in experiments with solutions containing $\left[\mathrm{S}_{2} \mathrm{O}_{8}^{2-}\right]=1.5 \times 10^{-2} \mathrm{M}$ and $\left[\mathrm{Cl}^{-}\right]=0.45 \mathrm{M}$ in the presence (curve $a$ ) and absence (curve b) of $1.04 \times 10^{-5} \mathrm{M}$ of MT. The grey lines stand for the fitting to Eq. (1). Left inset: Plots of $k_{F}$ vs [MT] for experiments with $\left[\mathrm{Cl}^{-}\right]=0.345(\bullet)$ and $0.5 \mathrm{M}(\triangle)$. Right inset: Plot of the slopes " $\mathrm{S}$ " vs. $\left[\mathrm{Cl}^{-}\right]^{-1}$. The fitting to a straight line yields $r^{2}=0.32$. Note that the percentage probability that five data points of two uncorrelated variables give a correlation coefficient $|r|=0.56$ is $\sim 35 \%$ (Taylor, 1982). The symbols size is on the order of the experimental error, unless otherwise specified by the error bars.

absence of MT). For both insecticides, the transient absorbance at $340 \mathrm{~nm}$ could be well fitted to a mixed first and second order decay rate law given by Eq. (1), also shown in Fig. 1.

$A^{\lambda}(t)=\frac{k_{F}}{\left(\frac{2 \times k_{B}}{\varepsilon^{\lambda} \times l}+\frac{k_{F}}{A_{o}^{\lambda}}\right) \times e^{k_{F} \times t}-\frac{2 \times k_{B}}{\varepsilon^{\lambda} \times l}}$

$A^{\lambda}(t)$ in Eq. (1) is the absorbance at time $t$ and wavelength $\lambda$; $k_{\mathrm{B}}$ and $k_{\mathrm{F}}$ stand for the second and the pseudo first-order decay rate constants, respectively; $\varepsilon^{\lambda}$ is the molar absorption coefficient at wavelength $\lambda, A_{\mathrm{o}}^{\lambda}$ is the absorbance immediately after the flash of light, and $l$ is the optical path length of the cell.

The parameter $k_{\mathrm{B}}$ did not depend on the insecticide concentration, as expected for the recombination of $\mathrm{Cl}_{2}^{-}$ radical ions (reaction (5)). On the other hand, for each amount of chloride, $k_{\mathrm{F}}$ depends on the insecticide (DM or MT) and on its concentration as shown in Fig. 1 left inset.

The effect of the insecticides on the decay rate of $\mathrm{Cl}_{2}^{-}$may be understood if reactions (6) and (7) efficiently compete with the decay reactions of $\mathrm{Cl}_{2}^{-}$and $\mathrm{Cl}$, reactions (5), (8), (9), and (10) in Table 1. The efficient removal of HO. radicals by the insecticides (reaction (12)) does not allow the attainment of equilibrium conditions for the complex reversible reaction system of $\mathrm{Cl} / \mathrm{Cl}_{2}^{-}$with water and hydroxide anions, which may be considered as simple first-order reactions schematized by reactions (8)-(11) (Mártire et al., 2001). For solutions of $\mathrm{pH}$ in the range from 3 to 6 and $\left[\mathrm{Cl}^{-}\right]>0.3 \mathrm{M}$, the conditions: $\mathrm{K}_{3,4} \times\left[\mathrm{Cl}^{-}\right]>1, k_{10} \times\left[\mathrm{HO}^{-}\right]<k_{9}$ and $k_{8} /\left(\mathrm{K}_{3,4} \times\left[\mathrm{Cl}^{-}\right]\right) \ll k_{9}$ apply (Alegre et al., 2000) (Mártire et al., 2001). With these considerations, the apparent first-order decay rate constant of $\mathrm{Cl}_{2}^{-}, k_{\mathrm{F}}$, is given by Eq. (2), for both MT and DM insecticides. The acronym INS stands for MT or DM.

$k_{\mathrm{F}}=k_{9}+\left[\frac{k_{7 \mathrm{INS}}}{\mathrm{K}_{3,4} \times\left[\mathrm{Cl}^{-}\right]}+k_{6 \mathrm{INS}}\right] \times[\mathrm{Ins}]$

Plots of $k_{\mathrm{F}}$ Us. [MT] or [DM] (Fig. 1 left inset) yield straight lines as expected from Eq. (2). The intercepts of these plots yield for both insecticides $k_{9}=(750 \pm 350)$, on the order expected for this rate constant (see Table 1). In turn, the slopes " INS" seem $_{\text {IN }}$ to be linearly correlated with $\left[\mathrm{Cl}^{-}\right]^{-1}$, in agreement with Eq. (2). The intercept of the linear plots of $S_{\text {INS }}$ vs. $\left[\mathrm{Cl}^{-}\right]^{-1}$ (as shown in Fig. 1 right inset for $\mathrm{MT})$ yield $k_{6 \mathrm{MT}}=(1.3 \pm 0.4) \times 10^{8} \mathrm{M}^{-1} \mathrm{~s}^{-1}$ and $k_{6 \mathrm{DM}}=(1.1 \pm 0.4) \times 10^{8} \mathrm{M}^{-1} \mathrm{~s}^{-1}$. However, the statistical analysis of the data indicates that there is a $35 \%$ probability that $\mathrm{S}_{\mathrm{INS}}$ is not correlated with $\left[\mathrm{Cl}^{-}\right]^{-1}$. If this is the case, the data points correspond to independent measures of $k_{6 I N S}$, which values are coincident, within the experimental error, with those obtained assuming a linear correlation of the variables. This situation may be understood considering that, even for the extreme case that reaction (7) were diffusioncontrolled $\left(k_{7 \mathrm{INS}} \sim 2 \times 10^{10} \mathrm{M}^{-1} \mathrm{~s}^{-1}\right)$, the condition $k_{7 \mathrm{INS}} /$ $\left(\mathrm{K}_{3,4} \times\left[\mathrm{Cl}^{-}\right] \ll k_{6 \text { INS }}\right.$ (see Eq. (2)) holds for $\left[\mathrm{Cl}^{-}\right]>0.3 \mathrm{M}$. Therefore, determination of a reliable value for $k_{\text {7INS }}$ is not possible from our experiments.

The reported rate constants for the reaction of hydroxyl radicals with $\mathrm{MT}$ and $\mathrm{DM}$ are $7.1 \times 10^{9} \mathrm{M}^{-1} \mathrm{~s}^{-1}$ and $8.5 \times 10^{9} \mathrm{M}^{-1} \mathrm{~s}^{-1}$, respectively (Marin et al., 2011), reaction (12) in Table 1. These values, ca. 50 times higher than those measured for $\mathrm{Cl}_{2}^{-}$, might explain the slower removal observed for both pesticides by solar photo-Fenton when performed in the presence of chloride ions under experimental conditions where the more efficient $\mathrm{HO} \cdot$ oxidant has been partly replaced by the milder $\mathrm{Cl}_{2}^{-}$radical.

\subsection{Organic transients formed after MT and DM reactions with $\mathrm{Cl}_{2}^{-}$radicals}

A bilinear analysis of the absorption traces obtained in the wavelength interval from 290 to $600 \mathrm{~nm}$ in experiments performed with $\left[\mathrm{S}_{2} \mathrm{O}_{8}^{2-}\right]=1.5 \times 10^{-2} \mathrm{M},\left[\mathrm{Cl}^{-}\right]=0.45 \mathrm{M}$ and either $[\mathrm{MT}]=6.25 \times 10^{-5} \mathrm{M}$ or $[\mathrm{DM}]=2.2 \times 10^{-4} \mathrm{M}$ showed the formation of two transients for each insecticide with spectra and decay profiles shown in Fig. 2a and b for MT and DM, respectively. Short-lived transients with absorption maxima in the range from 320 to $340 \mathrm{~nm}$ and lifetimes of 0.17 and $<0.10 \mathrm{~ms}$ were observed for MT and DM, respectively. Considering that the transient spectra resembles that of $\mathrm{Cl}_{2}^{--}$radicals (circles in Fig. $2 \mathrm{a}$ and $b$ ) and the observed lifetimes are on the order of those expected for $\mathrm{Cl}_{2}^{-}$radicals under each particular experimental condition, these transients were assigned to $\mathrm{Cl}_{2}^{--}$radicals.

The longer lived transients observed for MT and DM absorb in the $280-310 \mathrm{~nm}$ range (triangles in Fig. 2a and b). Considering that these intermediates are only observed in flashphotolysis experiments involving both, $\mathrm{Cl}_{2}^{--}$radicals and the insecticides, they are expected to be due to organic transients formed after reactions (6). Moreover, the concentration profiles (grey lines in the insets of Fig. $2 a$ and $b$ ) show half-rise times $\leq 200 \mu$ s (in the limit of our time window), as expected 


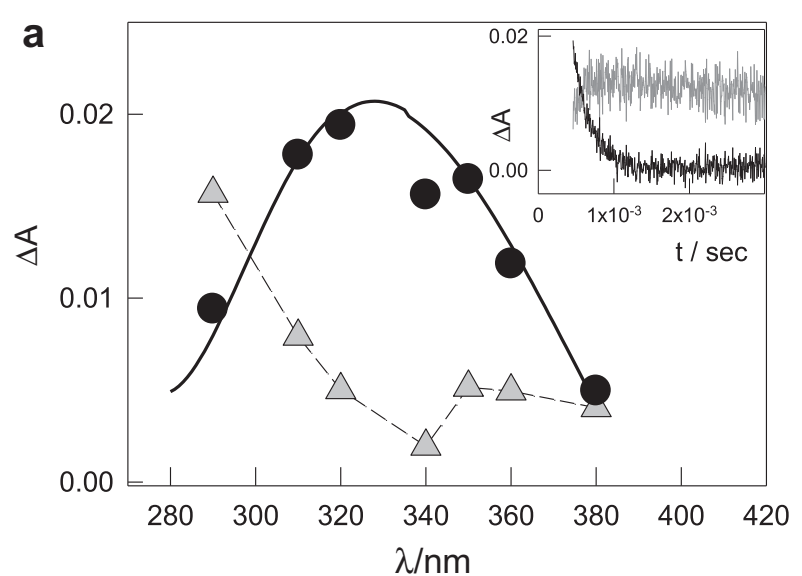

b

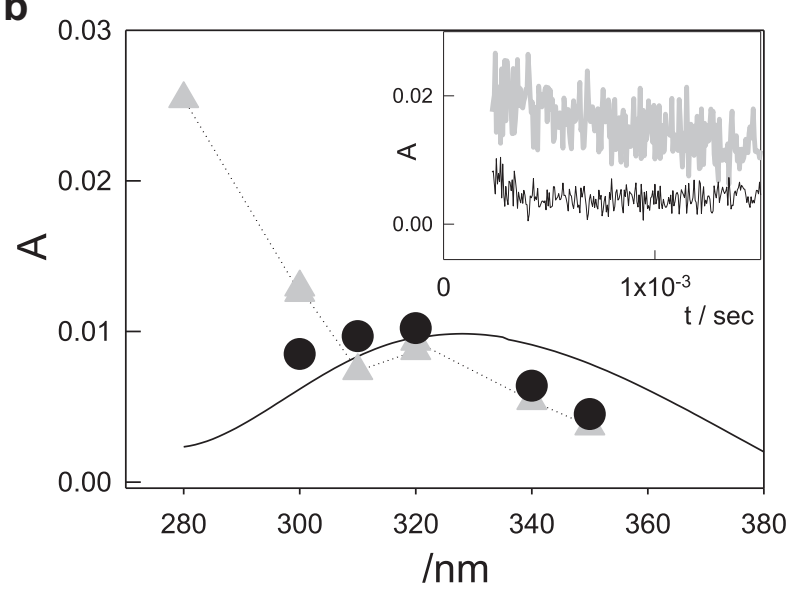

Fig. 2 - Transient spectra retrieved by a bilinear computer analysis of the absorption traces obtained from flashphotolysis experiments performed with air saturated solutions of $\mathrm{pH} 5.5$ containing $\left[\mathrm{S}_{2} \mathrm{O}_{8}^{2-}\right]=1.5 \times 10^{-2} \mathrm{M}$, $\left[\mathrm{Cl}^{-}\right]=0.45 \mathrm{M}$, and the insecticides: $[\mathrm{MT}]=6.25 \times 10^{-5} \mathrm{M}$ (plot $a$ ) and $[\mathrm{DM}]=2.2 \times 10^{-4} \mathrm{M}$ (plot $b$ ). The symbols $(0)$ and ( ) stand for the respective short- and long-lived transients, respectively. The solid line stands for the $\mathrm{Cl}_{2}^{-}$radical spectrum obtained in the absence of insecticides. Insets: Contribution of the short- (black curves) and long-lived (grey curves) transients to the absorbance of the traces at 320 and $290 \mathrm{~nm}$, respectively, for the experiments in the figure.

for transient species formed after the insecticide reactions with $\mathrm{Cl}_{2}^{-}$radicals. The transients decay is in the $\mathrm{ms}$ domain, independent on the presence of molecular oxygen. As will be discussed latter in the text, the long-lived transients are assigned to sulphenyl radical cations. Any contribution of the organic transients formed after reaction (7) to the observed spectra may be neglected under the present experimental conditions since $\mathrm{Cl}$ atoms are readily scavenged by $\mathrm{Cl}^{-}$as the condition $k_{3} \times\left[\mathrm{Cl}^{-}\right] \gg k_{7} \times$ [Ins] holds, even for a diffusioncontrolled reaction (7).

\subsection{Identification of stable reaction products}

Pesticide solutions containing $\mathrm{S}_{2} \mathrm{O}_{8}^{2-}$ and $\mathrm{Cl}^{-}$anions were continuously irradiated at $254 \mathrm{~nm}$ during $10 \mathrm{~min}$ and then analyzed by GC-MS. Table 2 shows the mass to charge ratios, retention times, and assigned chemical structures of the observed byproducts.

Reactive $\mathrm{SO}_{4}^{-}$and $\mathrm{HO}^{*}$ radicals are also present in the reaction mixture; $\mathrm{SO}_{4}^{--}$radicals as precursors of $\mathrm{Cl} / \mathrm{Cl}_{2}^{--}$radicals, reactions (1) and (2), and $\mathrm{HO}^{\circ}$ radicals as a consequence of $\mathrm{Cl} / \mathrm{Cl}_{2}^{-}$reactions with water, reactions (8)-(11). Since high concentrations of the insecticides were used in the continuous irradiation experiments performed to determine the products of reaction (6), the generation of detectable concentrations of products due to the reaction between the insecticides and $\mathrm{HO}^{\circ}$ (reaction (12)), $\mathrm{SO}_{4}^{--}$(reaction (13)), and $\mathrm{Cl}$ radicals (reaction (7)), should not be ruled out. To evaluate the magnitude of this contribution, a computer program was built to simulate the generation of oxidized products formed from the different reactions. To this purpose, reactions (1)-(13) along with the reactions of $\mathrm{SO}_{4}^{--}$with water and peroxodisulfate ions (reactions (14) and (15), respectively), and $\mathrm{SO}_{4}^{--}$ bimolecular recombination (reaction (16)), were taken into account. The reaction rate constants used are those depicted in Table 1. Initial parameters were the analytical concentrations of reactants and the continuous irradiation conditions. To this purpose, $\mathrm{SO}_{4}^{-}$radicals were assumed to be formed at a rate of $8.5 \times 10^{-6} \mathrm{M} \mathrm{s}^{-1}$ as expected for the irradiation with a $15 \mathrm{~W}$ low-pressure $\mathrm{Hg}$ lamp (incident photonic flux at $\left.254 \mathrm{~nm}=6.1 \times 10^{-6} \mathrm{E} \mathrm{L}^{-1} \mathrm{~s}^{-1}\right)$ of a $0.25 \mathrm{M} \mathrm{S}_{2} \mathrm{O}_{8}^{-2}$ solution $\left(\mathrm{S}_{2} \mathrm{O}_{8}^{-2}\right.$ photodissociation quantum yield 0.5-0.7 (Criquet and Karpel Vel Leitner, 2009) contained in a $2.5 \mathrm{~cm}$ optical pathway reactor.

The simulation shows that the generation of products from the reactions of the insecticides with $\mathrm{SO}_{4}^{--}$and $\mathrm{Cl}$ radicals under the experimental conditions used are negligible while those for the reaction of DM and MT with HO are 5 and $13 \%$, respectively, as shown in Table 3 . Therefore, the identified products are mainly formed after the reaction of the insecticides with $\mathrm{Cl}_{2}^{-}$.

\subsection{Reaction mechanisms}

The $\mathrm{Cl}_{2}^{-}$radicals are prone to undergo charge transfer reactions with most substrates, and in particular with organic sulfides (Mishra et al., 2005). In fact, it was early reported by Asmus and Hiller (Asmus et al., 1977; Asmus and Bonifačić, 1980; Hiller and Asmus, 1981) that $\mathrm{Cl}_{2}^{--}$radicals are involved in an exchange equilibrium with sulfides yielding chloride anions and neutral radicals comprising a three electron sulfur-chlorine bond (represented as $\mathrm{S}: \mathrm{Cl}$ ) and absorbing around $390 \mathrm{~nm}$. The latter radicals may further dissociate to $\mathrm{Cl}^{-}$anions and sulphenyl radical cations, which exhibit absorption in the $300-400 \mathrm{~nm}$ range depending on the substituents (Jonah and Madhava Rao, 2001; Asmus et al., 1977; Varmenot et al., 2001). Formation of sulphenyl radical cations of MT and DM is supported by the nature of the reaction products and the fact that the observed organic transients do not react with $\mathrm{O}_{2}$ (Glass, 1999). Moreover, MT has been reported to undergo a charge transfer reaction with the organic photocatalysts triphenylpyrylium and triphenylthiapyrylium (Arques et al., 2009).

Scheme 2 shows the proposed mechanism for MT. A charge transfer mechanism between the insecticide and $\mathrm{Cl}_{2}^{-}$ 
Table 2 - Oxidation byproducts formed after the reaction of $\mathrm{Cl}_{2}^{-}$with the insecticides. GC retention times, $R_{\mathrm{t}}$, MS molecular ions (when observed) and characteristic fragmentation ion peaks are given together with assigned products.

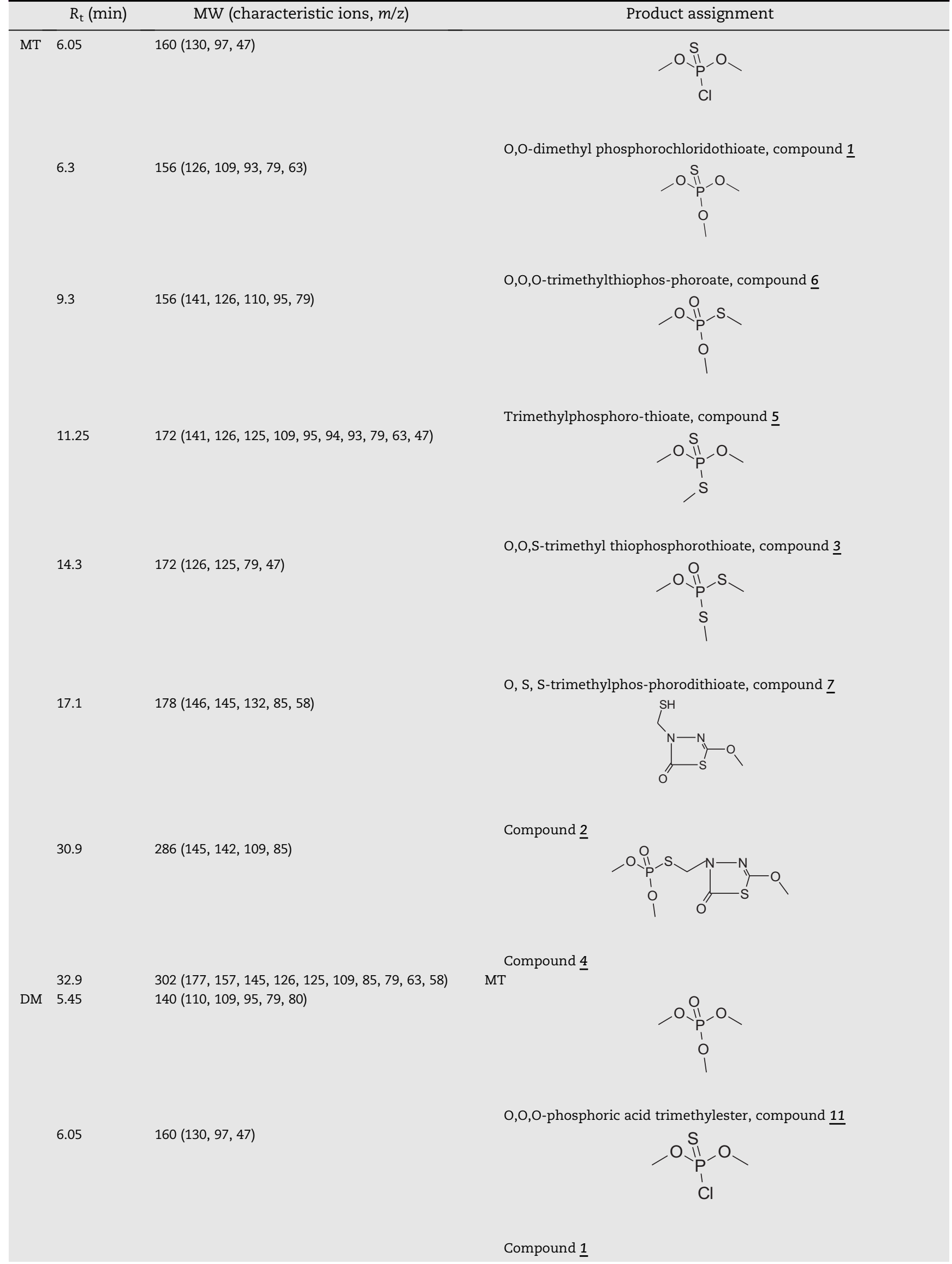


Table 2 - (continued)

\begin{tabular}{|c|c|c|}
\hline$R_{\mathrm{t}}$ (min) & MW (characteristic ions, $\mathrm{m} / \mathrm{z}$ ) & Product assignment \\
\hline \multirow[t]{2}{*}{8.8} & $105(58,48)$ & \\
\hline & & Compound $\underline{8}$ \\
\hline \multirow[t]{2}{*}{9.4} & $156(141,126,110,95,79)$ & \\
\hline & & Compound $\underline{5}$ \\
\hline \multirow[t]{2}{*}{9.9} & $119(73,61,58)$ & \\
\hline & & 2-S-methyl-(N-methyl) acetamide, compound 10 \\
\hline \multirow[t]{2}{*}{11.3} & $172(125,93,79)$ & \\
\hline & & Compound $\underline{3}$ \\
\hline \multirow[t]{2}{*}{16.6} & $151(105,58)$ & \\
\hline & & N-methyl, acetomethyldi-sulfide, compound $\underline{9}$ \\
\hline 17.5 and 18.4 & $(181,124,79,46)$ & Compound $\underline{13}\left(\mathrm{CH}_{3} \mathrm{O}\right)_{2} \mathrm{PO}\left(\mathrm{SC}_{2} \mathrm{H}_{2} \mathrm{ONO}_{2}\right)$ \\
\hline 25.3 & $229(125,93,87)$ & $\mathrm{DM}$ \\
\hline \multirow[t]{2}{*}{27} & $213(182,141,126,79,58)$ & $-0,0$ \\
\hline & & $\begin{array}{l}\text { O,O-dimethyl-S-(N-methylcarbamoylmethyl) phosphorothioate } \\
\text { compound } 11\end{array}$ \\
\hline
\end{tabular}

radicals leads to the formation of the sulphenyl radical cation $\mathrm{MTS}^{+}$, reaction pathway (a). Chloride ions may further induce the heterolysis of $\mathrm{S}-\mathrm{P}$ bonds of $\mathrm{MTS}^{*+}$ to yield compound 1 and an organic radical leading to compound $\underline{2}$ after $\mathrm{H}$-atom

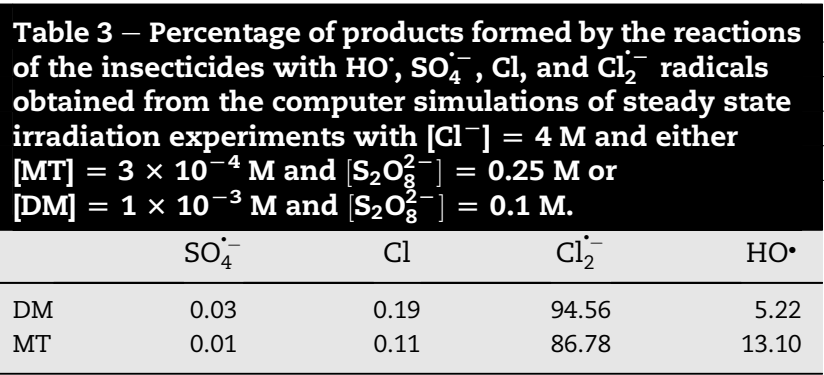

abstraction, pathway $(b)$. Otherwise, $\mathrm{C}_{\alpha}-\mathrm{N}$ fragmentation of MTS $^{++}$yields compound 3, pathway (c).

Organophosphorous compounds with the thiono $\mathrm{S}=\mathrm{P}$ structure are known to hydrolyze to their oxon forms, $\mathrm{O}=\mathrm{P}$, via specific base hydrolysis (Rav-Acha et al., 2007) and upon chlorination of their aqueous solutions (Tahara et al., 2006). Hypochlorite anions have also been found to act as a nucleophile accelerating MT hydrolysis (Duirk et al., 2008). No clear evidence on the oxon formation mechanism is obtained from the present study, as for solution pHs of 5.5 and after 10 min irradiation, hydrolysis is expected to be of little significance. Formation of compound 4 probably involves the interaction of $\mathrm{Cl}_{2}^{-}$with the $\mathrm{S}$ atom of the thiono structure followed by water addition and displacement of S, pathway (d). Further reaction between compound 4 and $\mathrm{Cl}_{2}^{--}$involving a sulphide radical 


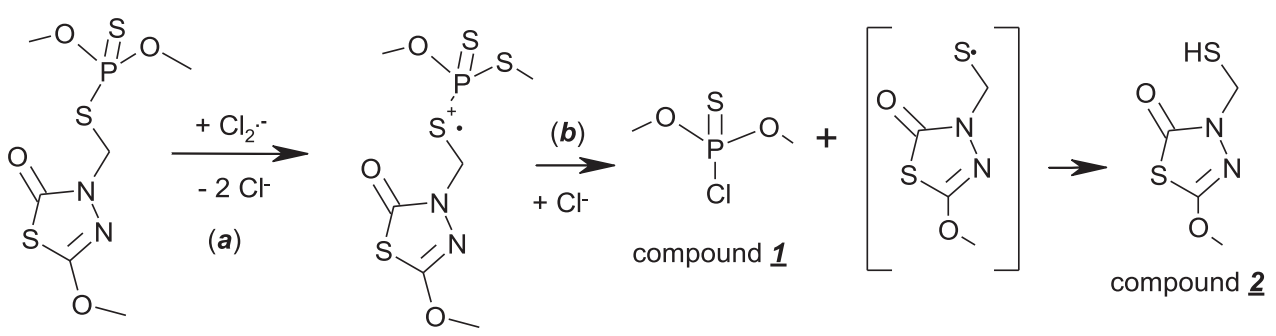

MT
(d) $\downarrow \begin{aligned} & +\mathrm{Cl}_{2}^{--},+\mathrm{H}_{2} \mathrm{O} \\ & \left(-\mathrm{SH} \cdot,-2 \mathrm{Cl}^{-},-\mathrm{H}^{+}\right)\end{aligned}$

MTS.+<smiles>COc1nn(CSP(=O)(OC)OC)c(=O)s1</smiles><smiles>COP(=O)(OC)SC</smiles>

compound $\underline{\mathbf{5}}$

compound $\underline{4}$

Scheme 2 - Proposed reaction mechanism for the reaction of $\mathrm{MT}$ with $\mathrm{Cl}_{2}^{-}$radical anions. Transients and stable compounds in brackets are proposed, but not detected.<smiles>CCSP(=S)(OC)OC</smiles>

compound $\underline{3}$

(g)<smiles>CC(C)CC(C)C(C)Cl</smiles>

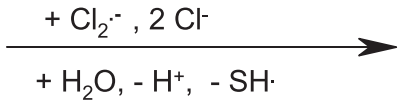

(f)<smiles>COP(=O)(OC)SC</smiles>

compound $\underline{\mathbf{5}}$<smiles>CC(Cl)C1CC1[Ge]Cl</smiles>

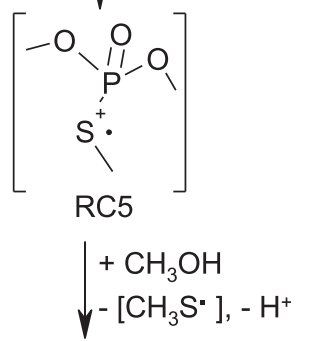<smiles>COCCO</smiles><smiles>COP(=O)(OC)OC</smiles>

compound $\underline{12}$

compound 1

Scheme 3 - Proposed reaction mechanism for the oxidation of compound 3 . Transients and stable compounds in brackets are proposed, but not detected. 
cation leads to the formation of compound $\underline{5}$, as depicted in reaction path $(e)$.

In Scheme 3, pathway (f) shows formation of compound 5 , the oxon derivative of compound $\underline{3}$. Further oxidation of compound 3 with $\mathrm{Cl}_{2}^{-}$radicals leads to the radical cation $\mathrm{RC} 3$, pathway $(g)$, which upon chloride addition yields compound 1 and $\mathrm{CH}_{3} \mathrm{SH}$. Methanol and $\mathrm{CH}_{3} \mathrm{SH}$ may be formed as a consequence of the degradation of the phosphoric acid methylesters and methylthioates byproducts to phosphate. Methanol is able to react with RC3 to yield compound 6 . Generation of $\mathrm{SH}_{2}$ and $\mathrm{CH}_{3} \mathrm{SH}$ in the reaction mixture, as also observed in the Fenton degradation of MT (Ballesteros et al., 2009), facilitates the $\mathrm{H}$-abstraction reactions proposed in Schemes 2-4.

Major degradation products were also detected in the case of DM (see Table 2). It is interesting to note that some of the products are coincident with those detected in MT degradation (compounds $1, \underline{3}$, and 5 ), which correspond to the degradation byproducts of the phosphothioesther moiety of the pesticides. Compounds $\underline{12}, \underline{11}, \underline{8}, \underline{5}$, and $\underline{3}$ were previously reported in the $\mathrm{TiO}_{2}$-mediated photocatalytic decomposition of DM (Evgenidou and Konstantinou, 2006; Calza and Massolino, 2008) and these compounds, together with $\underline{11}, \underline{10}$ and 9 , in the thermal degradation of DM (Andreozzi et al.,
1999). Similar reaction paths to those observed for MT are likely to take place in the reaction of DM with $\mathrm{Cl}_{2}^{-}$radicals.

Scheme 4 shows the charge transfer mechanism between $\mathrm{DM}$ and $\mathrm{Cl}_{2}^{-}$leading to the formation of the corresponding Scentered radical cation $\mathrm{DMS}^{*}{ }^{+}$. Formation of compounds $\underline{1}$ and 8 may be explained by the heterolytic cleavage of the $\mathrm{S}-\mathrm{P}$ bond of DMS. ${ }^{+}$involving a sulphenyl radical (S*), reaction path (i). Rearrangement of radical $S^{*}$ and further heterolysis yielding a methyl sulphenyl radical and recombination of the latter with $S^{*}$ leads to the formation of compound 9 , reaction path (j). Otherwise, rearrangement of radical S. and further heterolysis yielding a methyl radical and recombination of the latter with $S^{*}$ leads to the formation of compound $\underline{10}$, reaction path $(k)$. On the other hand, $\mathrm{C}_{\alpha}-\mathrm{C}_{\beta}$ fragmentation (Schöneich et al., 2001) of DMS $^{*+}$ yields compound 3 , reaction path (l). Formation of the oxon derivative of DM, compound 11 , is also observed, as depicted in reaction path $(m)$. Further reaction of compound 11 and $\mathrm{Cl}_{2}^{--}$radical anions may lead to the formation of compound $\underline{5}$, as depicted in reaction path $(n)$.

As discussed above, compound 3 also leads to the formation of 5 (see Scheme 3). Oxidation of compound $\underline{5}$ with $\mathrm{Cl}_{2}^{-}$radicals leads to the radical cation RC5, pathway $(h)$. Addition of methanol to RC5 may lead to the formation of compound 12 .

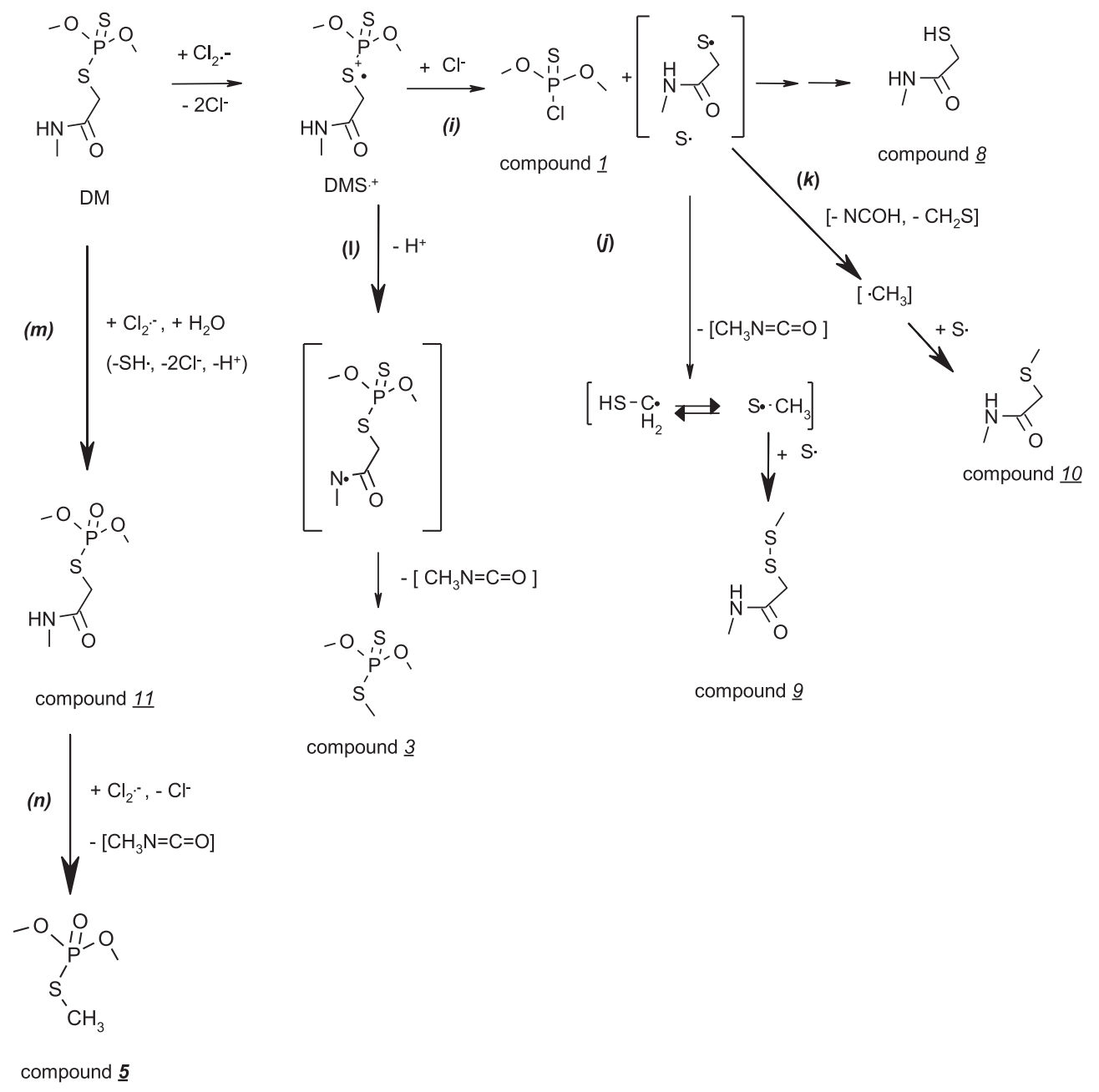

Scheme 4 - Proposed reaction mechanism for the reaction of DM with chloride radical anions. Transients and stable compounds in brackets are proposed, but not detected. 
Schemes 2-4 consider the possible generation of $\mathrm{N}-$, $\mathrm{S}$ - and $\mathrm{C}$-centered radicals which are known to efficiently react with molecular oxygen to yield oxidized products (Wlodek, 2002; Neta et al., 1990). Therefore, reactions with $\mathrm{O}_{2}$ cannot be neglected. In fact, compound $\underline{13}$ has been identified as an $\mathrm{N}$ oxidized product, probably formed after $\mathrm{O}_{2}$ reaction with $\mathrm{N}$ centered radicals such as those formed after reaction path (i) in Scheme 4. Molecular oxygen reactions involving ${ }^{\circ} \mathrm{SCH}_{3}$ and ${ }^{\circ} \mathrm{CH}_{3}$ radicals yield $\mathrm{CO}_{2}$, in agreement with the total organic carbon depletion observed during the course of the reaction.

O,O-dimethyl phosphorochloridothioate is the main chlorinated byproduct detected after the reaction of both, MT and DM with $\mathrm{Cl}_{2}^{-}$. Because of its toxicity, this compound is environmentally relevant. On the other hand, compounds $\underline{4}, \underline{5}$ and $\underline{11}$ are expected to show an increased toxicity relative to their precursors since the thiophosphate $(\mathrm{P}=\mathrm{S})$ moiety is replaced by the more toxic oxon $(\mathrm{P}=\mathrm{O})$ group (Tahara et al., 2006; Duirk et al., 2008). As generation of $\mathrm{Cl}_{2}^{-}$has been reported in the photoFenton process in the presence of chlorides (Machulek et al., 2007), formation of toxic compounds in photo-Fenton reaction under these conditions should not be ruled out. In fact, the small decrease in the biodegradability observed for DM and MT mixtures treated by solar photo-Fenton (Soler et al., 2009) in the presence of $\mathrm{Cl}^{-}$compared to experiments in its absence may be attributed to the different reaction products formed.

\section{Discussion}

The presence of chloride anions in polluted waters generally reduces the AOPs depletion efficiency of organic pollutants because of the scavenging of hydroxyl radicals by chloride anions (Fang et al., 2012). Chlorine and $\mathrm{Cl}_{2}^{-}$radicals formed in these systems may also initiate the oxidation of pollutants thus minimizing the negative effect of $\mathrm{Cl}^{-}$on AOP efficiency. In fact, we found here that the insecticides methidathion and dimethoate efficiently react by an electron transfer pathway with $\mathrm{Cl}_{2}^{-}$radicals. Therefore, these insecticides might be expected to be degraded by AOPs even in the presence of chloride anions. However, toxic chlorine-containing products may form under these conditions.

Because chlorine, $\mathrm{Cl}_{2}^{-}$, and $\mathrm{HO}^{*}$ radicals are interrelated by a complex scheme of reactions (see Table 1), predictions on the effect of $\mathrm{Cl}^{-}$on the depletion rates of the insecticides are not straightforward. To understand the behavior of the reaction system, the depletion of MD and MT in contaminated waters containing $\left[\mathrm{Cl}^{-}\right]=0.0,10^{-4}, 10^{-3}, 10^{-2}$, and $0.4 \mathrm{M}$ was modeled assuming an artificial $\mathrm{UV} / \mathrm{H}_{2} \mathrm{O}_{2}$ procedure producing $\mathrm{HO}$ radicals at a rate of $8.5 \times 10^{-6} \mathrm{M} \mathrm{s}^{-1}$. To this purpose, a $10 \mathrm{mM} \mathrm{H}_{2} \mathrm{O}_{2}$ solution contained in a $2 \mathrm{~cm}$ optical pathway reactor irradiated with a $25 \mathrm{~W}$ low-pressure $\mathrm{Hg}$ lamp, $2 \times 10^{-5} \mathrm{E} \mathrm{L} \mathrm{L}^{-1} \mathrm{~s}^{-1}$ incident photonic flux at $254 \mathrm{~nm}$, was considered. A minimum reaction mechanism consisting of reactions (3)-(12), and $\mathrm{HO}^{*}$ radical recombination, reaction (17), was considered. The system was allowed to evolve until a steady concentration of $\mathrm{Cl}, \mathrm{Cl}_{2}^{-}$, and $\mathrm{HO}^{*}$ radicals was attained and the concentration of products linearly increased with the reaction time. To compare the amount of products obtained in the presence and absence of chloride ions, an arbitrary value of $100 \%$ was assigned to the total molar concentration of products simulated in its absence. Simulation of high insecticide conversions was avoided, since the number of reactions of unknown rate constants geometrically increases with the increasing number of reaction products.

The effect of $\mathrm{pH}$ due to reaction (10) is negligible up to 9. Fig. 3 shows that the presence of chloride anions in the range from $10^{-4}$ to $0.4 \mathrm{M}$ inhibits the depletion efficiency of $6.25 \times 10^{-5} \mathrm{MT}$, though it does not follow a linear correlation with $\left[\mathrm{Cl}^{-}\right]$. Chloride anion concentrations $>10^{-4} \mathrm{M}$ are already capable of scavenging $\mathrm{HO}^{\circ}$ radicals. However, the higher $\left[\mathrm{Cl}_{2}^{-}\right]:[\mathrm{Cl}]$ ratios established for higher $\left[\mathrm{Cl}^{-}\right]$(reversible reactions (3) and (4)) and the good efficiency of the insecticide reaction with $\mathrm{Cl}_{2}^{-}$radicals (reaction (6)) lead to a partial recuperation of MT degradation capacity for $\left[\mathrm{Cl}^{-}\right]>10^{-3} \mathrm{M}$. In fact, for $\left[\mathrm{Cl}^{-}\right]=10^{-3} \mathrm{M}, \mathrm{MT}$ is depleted by $\mathrm{HO}, \mathrm{Cl}$ and $\mathrm{Cl}_{2}^{-}$ radicals, while for $\left[\mathrm{Cl}^{-}\right]=0.4 \mathrm{M}$, depletion is mainly due to $\mathrm{Cl}_{2}^{-}$ radicals. Moreover, Fig. 3 inset shows that the extent of inhibition also depends on the concentration of insecticide, as the lower insecticide concentrations show the higher decrease in the degradation efficiency even for $\left[\mathrm{Cl}^{-}\right]$as low as $10^{-4} \mathrm{M}$. A similar discussion applies to DM. An important consequence of the depletion of $\mathrm{MT}$ and $\mathrm{DM}$ by $\mathrm{Cl}_{2}^{-}$radicals is the detrimental formation of toxic byproducts.

The previous discussion further supports the participation of $\mathrm{Cl}_{2}^{--}$radicals unexpected effects on AOPs efficiency. Yang et al. (2005) studied the methylene blue (MB) and orange II (OII) degradation by $\mathrm{TiO}_{2} / \mathrm{UV}$-light in the presence of $\left[\mathrm{Cl}^{-}\right]$. These authors reported little influence on the degradation efficiency of both dyes in the presence of $\left[\mathrm{Cl}^{-}\right]<0.01 \mathrm{~mol} / \mathrm{L}$. However, for $\left[\mathrm{Cl}^{-}\right]>0.10 \mathrm{~mol} / \mathrm{L}$ they reported opposite effects: a significant degradation inhibition was observed for $\mathrm{MB}$ while OII showed an enhanced degradation. Also, $\mathrm{Cl}_{2}^{-}$radicals may also be responsible for the increased decolorization of Orange

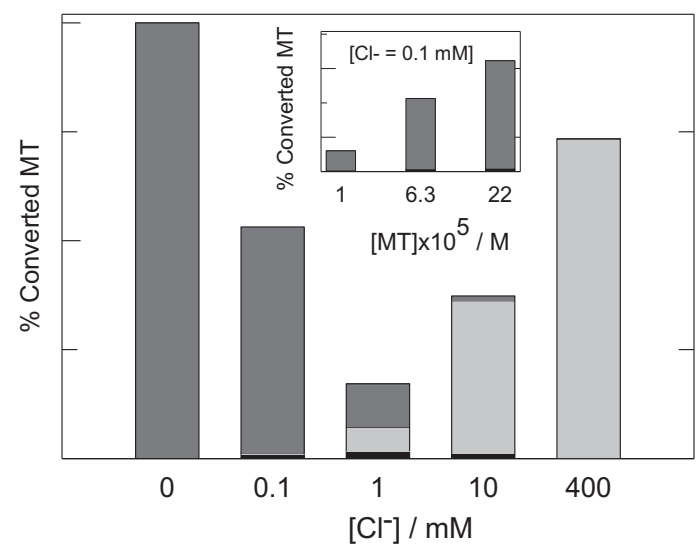

Fig. 3 - Expected consumption efficiency of MT during treatment by an artificial AOP producing HO radicals at a rate of $8.5 \times 10^{-6} \mathrm{M} \mathrm{s}^{-1}$. Polluted waters of $\mathrm{pH} 3$ containing $[\mathrm{MT}]=6.25 \times 10^{-5}$ and different $\left[\mathrm{Cl}^{-}\right]$were considered. The consumption due to the different scavengers is depicted as: dark grey: $\mathrm{HO}$, light grey: $\mathrm{Cl}_{2}^{-}$, black: Cl. Inset: Expected effect on the consumption efficiency of MT during treatment by the same artificial AOP of polluted waters of $\mathrm{pH} 3$ containing $\left[\mathrm{Cl}^{-}\right]=1 \times 10^{-4} \mathrm{M}$ and different [MT]. The \% converted MT in this plot is normalized to that observed in the absence of chloride anions for the same MT concentration. 
7 by peroxodisulfate in the presence of $0.1 \mathrm{M}$ chloride anions (Wang et al., 2011).

\section{Conclusion}

The phosphor-containing pesticides methidathion (MT) and dimethoate (DM) chemically react with $\mathrm{Cl}_{2}^{-}$radical anions with rate constants $(1.3 \pm 0.4) \times 10^{8}$ and $(1.1 \pm 0.4) \times 10^{8} \mathrm{M}^{-1} \mathrm{~s}^{-1}$, respectively. The sulfide group of the insecticides is the preferred site of attack initiating the degradation of the insecticides. Chlorinated byproducts were observed among the identified degradation products.

Computer simulation models predict that chloride anions present in polluted waters are able to scavenge the active oxidizing radicals produced by the AOP technologies to generate $\mathrm{Cl}$ atoms and $\mathrm{Cl}_{2}^{-}$radicals. Because of the efficient reactions of $\mathrm{MT}$ and $\mathrm{DM}$ with $\mathrm{Cl}_{2}^{-}$radicals, these processes are expected to have an important contribution in the AOP treatment of the insecticide's contaminated waters also containing high levels of chloride anions. However, toxic products are formed under these conditions.

\section{Acknowledgments}

This research was financially supported by Consejo Nacional de Investigaciones Científicas y Técnicas (CONICET), Agencia Nacional de Promoción Científica y Tecnológica (Argentina, project PICT 2007 number 00308), and Agencia Española de Cooperación Internacional (project A/8199/07). MCG, JAR and $\mathrm{PC}$ are research members of Consejo Nacional de Investigaciones Científicas y Técnicas (CONICET), Argentina. D.O.M. is a research member of CICPBA, Argentina. This research was supported by the grant PIP 112-200801-00356 from CONICET.

\section{R E F E R E N C E S}

Adams, D.J., Barlow, S., Buxton, G.V., Malone, T., Salmon, G.A., 1995. Evaluation of the stability constant of $\mathrm{Cl} 2$ in neutral aqueous solution. Journal of the Chemical Society, Faraday Transactions 91 (18), 3303-3305.

Alegre, M.L., Geronés, M., Rosso, J.A., Bertolotti, S.G., Braun, A.M., Mártire, D.O., Gonzalez, M.C., 2000. Kinetic study of the reactions of chlorine atoms and $\mathrm{Cl}_{2}^{--}$radical anions in aqueous solutions. 1. Reaction with benzene. Journal of Physical Chemistry A 104 (14), 3117-3125.

Andreozzi, R., Ialongo, G., Marotta, R., Sanchirico, R., 1999. The thermal decomposition of dimethoate. Journal of Hazardous Materials 64 (3), 283-294.

Arques, A., Amat, A.M., Santos-Juanes, L., Vercher, R.F., Marín, M.L., Miranda, M.A., 2009. Abatement of methidathion and carbaryl from aqueous solutions using organic photocatalysts. Catalysis Today 144 (1-2), 106-111.

Asmus, K.D., Bonifačić, M., 1980. Stabilization of oxidized sulphur centres by halide ions. Formation and properties of R2S $\therefore \mathrm{X}$ radicals in aqueous solutions. Journal of the Chemical Society, Perkin Transactions 2, 758-762.

Asmus, K.D., Bahnemann, D., Bonifačić, M., Gillis, H.A., 1977. Free radical oxidation of organic sulphur compounds in aqueous solution. Faraday Discussions of the Chemical Society 63 (0), 213-225.

Ballesteros, M.M., Sánchez Pérez, J.A., Casas López, J.L., Oller, I., Malato Rodríguez, S., 2009. Degradation of a four-pesticide mixture by combined photo-Fenton and biological oxidation. Water Research 43 (3), 653-660.

Boncz, M.A., Bruning, H., Rulkens, W.H., Zuilhof, H., Sudhölter, J.R.E., 2005. The effect of salts on ozone oxidation processes. Ozone: Science and Engineering 27, 287-292.

Buxton, G.V., Bydder, M., Salmon, G.A., 1998. Reactivity of chlorine atoms in aqueous solution. Part 1. Journal of the Chemical Society, Faraday Transactions 94 (5), 653-657.

Calza, P., Massolino, C., 2008. Light induced transformations of selected organophosphorus pesticides on titanium dioxide: pathways and by-products evaluation using LC-MS technique. Journal of Photochemistry and Photobiology A: Chemistry 199 (1), 42-49.

Chong, M.N., Jin, Bo, Chow, C.W.K., Saint, C., 2010. Recent developments in photocatalytic water treatment technology: a review. Water Research 44, 2997-3027.

Criquet, J., Karpel Vel Leitner, N., 2009. Degradation of acetic acid with sulfate radical generated by persulfate ions photolysis. Chemosphere 77 (2), 194-200.

De Laat, J., Le, T.G., 2006. Effects of chloride ions on the iron(III)catalyzed decomposition of hydrogen peroxide and on the efficiency of the Fenton-like oxidation process. Applied Catalysis B: Environmental 66 (1-2), 137.

Dell'Arciprete, M.L., Soler, J., Santos-Juanes, L., Arques, A., Mártire, D.O., Furlong, J., Gonzalez, M.C., 2010. Reactivity of neonicotinoid insecticides with carbonate radicals. Water Research 46, 3479-3489.

Dell'Arciprete, M.L., Santos-Juanes, L., Arques, A., Vercher, R.F., Amat, A.M., Furlong, J.P., Mártire, D.O., Gonzalez, M.C., 2012. Reactivity of neonicotinoid pesticides with singlet oxygen. Catalysis Today 151 (1-2), 137-142.

Duirk, S.E., Desetto, L.M., Davis, G.M., 2008. Fate of High Priority Pesticides During Drinking Water Treatment. Document by the U.S. Environmental Protection Agency, Office of Research and Development, Washington DC. 20460.

Evgenidou, E., Konstantinou, I., 2006. Study of the removal of dichlorvos and dimethoate in a titanium dioxide mediated photocatalytic process through the examination of intermediates and the reaction mechanism. Journal of Hazardous Materials 137 (2), 1056-1064.

Fang, G.D., Dionysiou, D., Wang, Y., Al-Abed, S.R., Zhou, D.M., 2012. Sulfate radical-based degradation of polychlorinated biphenyls: effects of chloride ion and reaction kinetics. Journal of Hazardous Materials 227-228, 394-401.

George, C., Chovelon, J.M., 2002. A laser flash photolysis study of the decay of $\mathrm{SO}_{4}^{-}$and $\mathrm{Cl}_{2}^{-}$radical anions in the presence of $\mathrm{Cl}-$ in aqueous solutions. Chemosphere 47 (4), 385-393.

Glass, R.S., 1999. Sulfur Radical Cations. Topics in Current Chemistry, vol. 205. Springer-Verlag Berlin Heidelberg, p. 1.

Herrmann, H., Reese, A., Zelhrer, R., 1995. Time-resolved UV/VIS diode array radical anions in aqueous solution absorption spectroscopy of $\mathrm{SO}_{x}^{-}(x=3,4,5)$. Journal of Molecular Structure 348 (4), 183-186.

Hiller, K.O., Asmus, K.-D., 1981. Oxidation of methionine by X in aqueous solution and characterization of some three-electron bonded intermediates. A pulse radiolysis study. International Journal of Radiation Biology 40 (6), 583-595.

Jonah, C.D., Madhava Rao, B.S., 2001. Radiation Chemistry: Present Status and Future Trends, first ed. Elsevier, Amsterdam, The Netherland, p. 755 (Chapter 4).

Liu, H., Zhao, H., Chen, S., Quan, X., Zhang, Y., 2010. Photochlorination of bisphenol A by UV-Vis light irradiation in saline solution: effects of iron, nitrate and citric acid. Environmental Chemistry 7 (6), 548-553. 
Machulek Jr., A., Moraes, J.E.F., Vautier-Giongo, C., Silverio, C.A., Friedrich, L.C., Nascimento, C.A.O., Gonzalez, M.C., Quina, F.H., 2007. Abatement of the inhibitory effect of chloride anions on the photo-Fenton process. Environmental Science \& Technology 41 (24), 8459-8463.

Marin, M.L., Lhiaubet-Vallet, V., Santos-Juanes, L., Soler, J., Gomis, J., Arques, A., Amat, A.M., Miranda, M.A., 2011. A photophysical approach to investigate the photooxidation mechanism of pesticides: hydroxyl radical versus electron transfer. Applied Catalysis B: Environmental 103 (1-2), 48-53.

Mártire, D.O., Rosso, J.A., Bertolotti, S.G., Carrillo Le Roux, G., Braun, A.M., Gonzalez, M.C., 2001. Kinetic study of the reaction of chlorine atoms and $\mathrm{Cl}_{2}^{-}$radicals anions in aqueous solutions. II. Reaction with chlorobenzene, toluene and benzoic acid. Journal of Physical Chemistry A 105 (22), 5385-5392.

Mishra, B., Priyadarsini, K.I., Mohan, H., 2005. Pulse radiolysis studies on reaction of ${ }^{\circ} \mathrm{OH}$ radical with $\mathrm{N}$-acetyl methionine in aqueous solution. Research on Chemical Intermediates 31 (7-8), 625-632.

Mora, V.C., Rosso, J.A., Mártire, D.O., Gonzalez, M.C., 2009. Phenol depletion by thermally activated peroxydisulfate in the presence of additives: a clean method for the degradation of pollutants. Chemosphere 75 (10), 1405-1409.

Nagarajan, V., Fessenden, R.W., 1985. Flash photolysis of transient radicals. 1. $\mathrm{X}_{2}^{--}$with $\mathrm{X}=\mathrm{Cl}, \mathrm{Br}, \mathrm{I}$, and SCN. Journal of Physical Chemistry 89, 2330-2335.

Neta, P., Huie, R.E., Ross, A.B., 1990. Rate constants for reactions of peroxyl radicals in fluid solutions. Journal of Physical and Chemical Reference Data 19, 413-513.

Oller, J., Gernjak, W., Maldonado, M.I., Fernandez, P., Blanco, J., Sanchez, J.A., Malato, S., 2005. Photocatalytic treatment of dimethoate by solar photocatalysis at pilot plant scale. Environmental Chemistry Letters 3 (5), 118-121.

Panno, S.V., Hackley, K.C., Hwang, H.H., Greenberg, S., Krapac, I.G., Landsberger, S., O’Kelly, D.J., April 22, 2002. Source identification of sodium and chloride contamination in natural waters: preliminary results. In: Proceedings of the 12th Annual Conference of the Illinois Groundwater Consortium Makanda (IL). www.siu.edu/orda/igc/index.html.

Peyton, G.R., 1990. Guidelines for the selection of a chemical model for advanced oxidation processes. A Symposium on Advanced Oxidation Processes for the Treatment of Contaminated Water and Air (Proceedings), June 4 and 5, 1990, Toronto.

Rav-Acha, C., Groisman, L., Mingelgrin, U., Kirson, Z., Sasson, Y., Gerstl, Z., 2007. A mechanistic study of methyl parathion hydrolysis by a bifunctional organoclay. Environmental Science \& Technology 41 (1), 106-111.
Ross, A.B., Mallard, W.G., Helman, W.P., Buxton, G.V., Huie, R.E., Neta, P., 1998. NDRL-NIST solution kinetics database, 1998. Available on the web at:. Notre Dame Radiation Laboratory, Notre Dame, IN and National Institute of Standards and Technology, Gaithersburg, MD (March 2012). http://kinetics. nist.gov/solution/.

San Roman, E., Gonzalez, M.C., 1989. Analysis of spectrally resolved kinetic data and time resolved spectra by bilinear regression. Journal of Physical Chemistry 93 (9), 3536-3540.

Schöneich, C., Miller, B., Hug, G.L., Bobrowski, K., Marciniak, B., 2001. Intermolecular complexes between sulfide radical cations from $\beta$-hydroxy sulfides and phosphate. Research on Chemical Intermediates 27 (1,2), 165-175.

Soler, J., Garcia-Ripoll, A., Hayek, N., Miro, P., Vicente, R., Arques, A., Amat, A.M., 2009. Effect of inorganic ions on the solar detoxification of water polluted with pesticides. Water Research 43 (18), 4441-4450.

Susnow, R.G., Dean, A.M., Green, W.H., Peczak, P., Broadbelt, L.J., 1997. Rate-based construction of kinetic models for complex systems. Journal of Physical Chemistry A 101, 3731-3740.

Tahara, M., Kubota, R., Nakazawa, H., Tokunaga, H., Nishimura, T., 2006. Analysis of active oxon forms of nine organophosphorous pesticides in water samples using gas chromatography with mass spectrometric detection. Journal of Health Science 52 (3), 313-319.

Taylor, J.R., 1982. An Introduction to Error Analysis. University Science Books, Mill Valley, California, p. 270.

Tsuneda, S., Ishihara, Y., Hamachi, M., Hirata, A., 2002. Inhibition effect of chlorine ion on hydroxyl radical generation in UV$\mathrm{H}_{2} \mathrm{O}_{2}$ process. Water Science and Technology 46 (11-12), 33-38.

Varmenot, N., Remita, S., Abedinzadeh, Z., Wisniowski, P., Strzelczak, G., Bobrowski, K., 2001. Oxidation processes of N,Sdiacetyl-L-cysteine ethyl ester: influence of S-acetylation. Journal of Physical Chemistry A 105, 6867-6875.

Wang, P., Yang, S., Shan, L., Niu, R., Shao, X., 2011. Involvements of chloride ion in decolorization of acid orange 7 by activated peroxydisulfate or peroxymonosulfate oxidation. Journal of Environmental Sciences 23 (11), 1799-1807.

Wlodek, L., 2002. Beneficial and harmful effects of thiols. Poland Journal of Pharmacology 54, 215-223.

Yang, S., Chen, Y., Lou, L., Wu, X., 2005. Involvement of chloride anion in photocatalytic process. Journal of Environmental Science (China) 17 (5), 761-765.

$\mathrm{Yu}, \mathrm{X} ., 2004$. Critical evaluation of rate constants and equilibrium constants of hydrogen peroxide photolysis in acidic aqueous solutions containing chloride ions. Journal of Physical and Chemical Reference Data 33 (3), 747-763. 